\title{
Healthcare Protection for Gig Workers: A Brief Case During Pandemic
}

\author{
Siciliya Mardian Yoel ${ }^{1, *}$ M. Wachid Hasym ${ }^{1}$
}

\author{
${ }^{1}$ Kadiri Islamic University \\ *Corresponding author. Email: siciliya@uniska-kediri.ac.id
}

\begin{abstract}
The social distancing strategy is one of the policy strategies in handling the COVID-19 and following other countries, in March 2020, Indonesia also established a Large-Scale Social Restriction (PSBB) policy which requires citizens to stop various activities in public spaces. However, not everyone can work safely from their home. People who work on the gig economy, for example delivery workers, cannot simply "work from home", their work requires them to travel to multiple places, where they are in close contact with significant numbers of people. Gig workers typically pay in low wages. Also gig companies do not generally offer healthcare coverage. The purpose of this research is to determine the form of legal protection that should be obtained by Gig Workers. Especially about their health care protection. This research will use socio legal research as the method, will serve to see the law in the real sense and examine how the law works in the society. Based on the research conducted in the period July - September 2020 in Kediri, it shows that not all gig workers are registered as BPJS Ketenagakerjaan members by employers but by themselves, and some of them do not even have health insurance at all.
\end{abstract}

Keywords: Pandemic, Health Care Protection, Gig Workers.

\section{INTRODUCTION}

Throughout 2020, most human activities must be carried out from inside the house. Humans are forced to slow down their movements and must limit themselves to socializing with other humans if they don't want to contract a disease that can threaten their lives. Corona Virus Disease 2019 (COVID-19) is the cause of this slowdown in human activity, the disease that was first reported in Wuhan, China on December 31, 2019, became a global health issue and was later declared a pandemic by the Worlds Health Organization (WHO).[1]

Starting from one country, this disease became a global health issue and was later declared a pandemic. To prevent further spread of disease, many countries in the world implement social and physical distancing policies or in Indonesia this policy is called Pembatasan Sosial Berskala Besar (PSBB). Following other countries, in March 2020, the Government of Indonesia also established a Large-Scale Social Restriction (PSBB) policy which requires citizens to stop various activities in public spaces, and encourages citizens to carry out various social, economic and political activities at a distance, from home or remotely. Since then, various activities have been carried out remotely, using online means - if possible, from their respective homes or residences.[2]

However, not everyone can work safely from their home. People who work on the gig economy are particularly vulnerable to coronavirus and other harmful pathogens. The gig economy consists of small tasks that the workers complete. These tasks can be anything from getting groceries to writing code. A gig worker can opt to work for a set amounts of hours (like choosing a shift) or work by the project. Once the task or shift is complete, the workers move on to the next gig. That might be another task with the same company, or something entirely different with another company.[3]

Though the term "gig economy" is relatively new, these nontraditional work arrangements have been around a long time. The growth of the gig economy, typified by online platforms and isolated 
independent workers, poses fundamental challenges to traditional models for regulating work and setting minimum standards. [4] It is not clear that existing regulations apply to gig workers, let alone that they can be effectively enforced in the digital economy. In fact, in some cases, evading traditional regulations appears to have been a key rationale for establishing digital businesses in the first place.[5]

Gig workers required to travel to multiple public store locations over the course of the day where they are in close contact with significant numbers of people and have brief but close contact with multiple customers in their homes. As coronavirus spreads, the increasing numbers of people will be placed in quarantine, that others will choose to isolate themselves by spending more of their time at home.

This condition could increase the use of gig delivery services, resulting in ever more exposure of gig workers. Gig workers often do not have access to paid sick time under the laws, so are also less likely than other workers to be able to simply take time off when sick. Because these jobs typically pay low wages, workers tend to be particularly financially precarious, seeing a doctor can be a challenge as well. Gig companies do not generally offer healthcare coverage, so gig workers are also less likely than other workers to have a quality, affordable medical plan.[6]

The purpose from this research is to determine the form of legal protection that should be obtained by Gig Workers, especially about their health care protection. This research will serve to see the law in the real sense and examine how the law works in the society.

\section{RESEARCH METHOD}

This research used socio legal research as the method. This research served to see the law in the real sense and examine how the law works in the society. This research described how healthcare protection for gig workers conduct at Kediri Region is. The approach method that be used in this research is sociological jurisprudence where the researcher needs to analyzed the regulation relating health care protection for workers, while sociologically this research will describe law enforcement and examine the effectiveness of the regulation, how it is implemented in the society and how effective it is in protecting the workers.

This research was conducted in the Kediri Regency in East Java Province, Indonesia. In this research, the data used are primary data obtained by distributing questionnaires and interviews with informants, also secondary data that obtained from literature studies on legislation, library books and other documents. The data and information obtained from the results of the study were analyzed by descriptive qualitative method, namely a method of analyzing data by grouping and selecting data obtained from research according to the quality and truth. The data is then connected with theories and legislation from literature studies, so that answers to the problems in this study are obtained.

\section{FINDINGS AND DISCUSSION}

Kediri is a city in East Java Province which is the third largest city in the province. The city itself has an area of $63.40 \mathrm{~km} 2$ with a population in 2012 of 312,331 people with a density of 4,926 people per km2.26 The City Government of Kediri declared "Tri Bina Kota" as the foundation of the development of the City of Kediri which relies on the education, trade, services and industry sectors. Based on that foundation, the Government commits itself to actively promote the industrial sector by strengthening the carrying capacity for industrial development as one of the bases for strengthening the reliable local economy. With its position as a developing urban area, Kediri has many industrial business units with varied business scales, covering large, medium and small industries. Large industries in Kediri are engaged in the sugar and cigarette industries, while for the Small and Medium Enterprises, the majority are engaged in food production and processing of agricultural products.

Like in the others city in Indonesia, in Kediri, guaranteeing self-protection is still not very popular for the workers. Indeed, there are private insurance company that offer many security services to protect themselves. However, as we all know that insurance from the private insurance company requires a lot of money. And many workers in Indonesia can't afford that.

However, Indonesian government and regulators always try to guarantee the rights of workers including health protection. Article 27 paragraph (2) of the 1945 Indonesian Constitution stated that every citizen has the right to decent work for humanity. In Article 28 D paragraph (2) of the 1945 Constitution of the Republic of Indonesia which states that everyone has the right to work and to receive fair and proper compensation and treatment in a work relationship. This constitutional provision shows that workers as citizens have the right to receive protection in carrying out work in order to achieve 
their welfare. The discussion is grouped into three main ideas, which are the healthcare regulation in the perspective of law, healthcare protection for workers in BPJS and how health care protection for gig workers implemented in Kediri

\subsection{Health care Regulation for Gig Workers on Indonesian Legislation}

Talking about legal protection for gig workers (including freelancers or daily workers) means discussing the rights of workers / laborers after carrying out their obligations. So far, employers who employ gig workers still see them as weak parties. Meanwhile, gig workers themselves do not understand what their rights and obligations are. In other words, gig workers only participated in the regulations made by employers. In fact, in a good cooperative relationship there is no party that is more dominant or more important because both employers and gig workers need each other. Therefore, this article will discuss what gig workers are entitled to.

The implementation of legal protection for gig workers, it must be in accordance with the applicable Manpower Regulations, namely Law Number 13 of 2003 concerning Manpower (Undang-undang Nomor 13 Tahun 2003 tentang Ketenagakerjaan, hence forward referred as Manpower Law), Decree of Minister of Manpower and Transmigration Republic of Indonesia No: Kep.100/Men/VI/2004 regarding Provisions on the Implementation of Certain Time Work Agreement and Transmigration of the Republic of Indonesia Decree No.100 of 2004 concerning Provisions for the Implementation of a Specific Time Work Agreement (Keputusan Menteri Tenaga Kerja dan Transmigrasi Republik Indonesia Nomor 100 Tahun 2004 Tentang Ketentuan Pelaksanaan Perjanjian Kerja Waktu Tertentu, hence forward referred as The Ministrial Decree 100/2004) and The Law no. 24 of 2011 on regarding Social Insurance Administration Organization (Undang-Undang Nomor 24 tahun 2011 tentang Badan Penyelenggara Jaminan Sosial, hence forward referred as BPJS Law).

The term gig workers do not have a single agreed-upon definition. It is often used to refer to a practice of working where an individual uses a digital platform provided by a company, accessed via an app or a website, to find and perform temporary, freelance, on-demand or gig work as a primary or supplementary source of income.[7] In Indonesia, people tends to equate gig workers with daily workers or freelancers which is the work arrangement is regulated in Decree of Minister of
Manpower and Transmigration Republic of Indonesia No: Kep.100/Men/VI/2004 regarding Provisions on the Implementation of Certain Time Work Agreement.[8]

Decree of Minister of Manpower and Transmigration Republic of Indonesia No: Kep.100/Men/VI/2004 regarding Provisions on the Implementation of Certain Time Work Agreement regulates the Daily Work Agreement in Articles 10 to 12 , which in the agreement must contain several conditions, including that agreement is implemented for certain jobs that change in terms of time and volume of work and wages based on attendance, the agreement is carried out provided that the workers works less than 21 days in 1 month, and in the event that a workers works 21 days or more for 3 consecutive months or more, the daily work agreement changes to a work Agreement for an Indefinite Period (Perjanjian Kerja Waktu Tertentu/ $P K W T$ ).[8] This regulation according to the researcher can implemented to a gig workers too.

The types of gig workers are divided based on units of yield and units of time. Gig Workers based on unit results are generally workers with certain professions and offer their expertise as a service by being given wages from their work independently. The work relationship ends immediately after the workers completes their work and without a work agreement, for example, a translator. While gig workers are based on time units, in general they work for employers and are given wages based on attendance. The work relationship is based on a work agreement, for example sales marketing.

It should be noted that even though gig workers are not explicitly mentioned in the Manpower Law, the guarantee of legal protection for workers, which is included in it also applies to gig workers, including protection for workers who need to be considered separately (persons with disabilities), prohibition on child labor, and special rights for women workers. The work agreement must be in a written form that contains at least the name and address of the employer, the name of the freelancer, the type of work performed, the amounts of wages, and the rights and obligations of each party including facilities as allowances.

In addition, one of the rights inherent in workers, including in this case gig workers, is the right to obtain protection for safety, health, morality, maintenance of work morale and treatment in accordance with human dignity and religious morals. Referring to the BPJS Law, Article 15 paragraph (1) states that: Employers are required to gradually 
register themselves and their Workers as Participants with the Social Insurance Administration Organization in accordance with the National Health Insurance program being followed.

The scope of the workforce social security program provided includes, among others, work accident insurance, death insurance, and / or health care insurance. Matters related to social security are very important so that they also need to be included in the work agreement. Non-state official employers, if they do not implement these provisions, may be subject to administrative sanctions as referred to in Article 17 paragraph (2) of the BPJS Law in the form of written warnings, fines, and / or not getting certain public services.

The regulations governing this matter are contained in Indonesian Government Regulation Number 86 of 2013 concerning Procedures for Imposing Administrative Sanctions to Non-State Officials Employers and Everyone, Apart from Employers, Workers, and Contribution Assistance Recipients in the Administration of Social Security (Peraturan Pemerintah Republik Indonesia Nomor 86 Tahun 2013 tentang Pengenaan Sanksi Administratif Kepada Pemberi Kerja Selain Penyelenggaran Negara dan Setiap Orang Selain Pemberi Kerja, Pekerja, dan Penerima Bantuan Iuran dalam Penyelenggaraan Jaminan Sosial, hence forward referred as Government Regulation No. 86/ 2013). This regulation guarantees that every employer who does not provide health insurance rights to their workers will be subject to administrative sanctions.

\subsection{Health Care Protection in BPJS Law}

In the midst of the difficulty of finding affordable social security for self-protection, a solution has finally emerged for all Indonesian people. The solution itself is called Badan Penyelenggara Jaminan Sosial (Social Insurance Administration Organization) which has two forms, namely BPJS Kesehatan (for Health Insurance) and BPJS Ketenagakerjaan (for Workers Insurance). For workers who want to get affordable future protection and guarantees, then the BPJS Ketenagakerjaan is the right choice. By registering as a member of BPJS Ketenagakerjaan, workers will get three types of insurance, namely:

a. Old-Age Insurance (Jaminan Hari Tua or JHT),

JHT or Old-Age Security is a program that will allow workers to get a guarantee in their old age from their savings balance. Uniquely, saving in the JHT program has a higher interest rate than saving in a bank. For this program itself, you need to deposit a fee of Rp. 40,000 per month. Workers can withdraw the balance from this JHT when they are no longer working.

b. Work Accidental Insurance (Jaminan Kecelakaan Kerja or JKK)

With the JKK (Work Accident Insurance) program, the participant will get insurance when they have a work accident by receiving compensation of Rp96,000,000. Even though these participants have only registered for a few days, when they experience a work accident, they will still receive compensation of $\mathrm{Rp}$. 96,000,000. However, this JKK cannot be disbursed like JHT. To join this program, a participant only needs to pay a monthly fee of IDR 20,000.

c. Death Insurance (Jaminan Kematian or JKM)

By joining the JKM program workers will receive death benefits of IDR 21,000,000. The monthly JKM fee itself is very affordable, amounting to IDR 6,000.

BPJS Ketenagakerjaan was formerly known as Jaminan Sosial Tenaga Kerja (Jamsostek or Social Insurance for Workers) which provided a social insurance program that provided protection for workers in Indonesia. But now, since Jamsostek changed its name to BPJS Ketenagakerjaan, workers outside the company or independent workers have also been able to register with BPJS Ketenagakerjaan insurance. With BPJS Ketenagakerjaan everyone who has a job outside of a work relationship such as traders, farmers, fishermen, bloggers, artists, athletes, motorcycle taxi drivers, gig workers and other independent workers can register in the BPJS Ketenagakerjaan program.

Since May 2015, BPJS has introduced the NonWage Recipient (Bukan Penerima Upah or BPU) program. With the new program, people who are classified as non-wage earners or who do not receive a regular salary (independent workers, including gig workers) can get guarantees from BPJS Ketenagakerjaan and have the same facilities as workers in the formal sector. The BPU program itself established because of the lack of interest of the people who are categorized as independent workers to be participant to BPJS Ketenagakerjaan.

There is something interesting about the BPU program itself for the participants. And this interesting thing should make these self-employed 
workers more enthusiastic about signing up. The interesting thing about this BPU program is that it provides special facilities that are not owned by BPJS Ketenagakerjaan participants from the category of permanent workers' participants. Some of the facilities that will be obtained by independent workers from this BPU program include:

a. Obtain Care and Medical Facilities

If they experience a work accident, workers have the right to receive care facilities at a first-class government hospital where medical expenses can reach IDR 20 million. According to the BPJS Ketenagakerjaan, this IDR 20 million figure can still change until it reaches an infinite number. This has been discussed in itself and there are operational and technical guidelines.

b. Get Full Cover

If worker can't work as the result from occupational disease or work accident, BPJS Ketenagakerjaan will cover in full according to the income it reports. For example, if the workers had a work accident and cannot work for three months, then for three months he will be covered, according to the reported income.

c. Get a Death Insurance

Another facility that will be obtained by selfemployed workers is death insurance. If the person concerned dies normally, the heir will receive IDR 21 million. However, if a participant die due to a work accident, they will get 48 times the standard income.

d. Cheap and Affordable Fees

Another facility that can be obtained by independent workers from the BPU program is an inexpensive and affordable fee. Indeed, the presence of the BPJS is very cheap for a measure of insurance like the insurance concept, but for this BPU program only 1 percent of income is charged for work accident insurance and 0.30 percent for death insurance itself.

Participants of the BPU program must pay insurance premium independently. Unless they are a worker from a company whose contributions will be deducted from the salary of the workers concerned, plus contributions from the company where the employee work. For workers who are categorized as poor, their social security membership contributions must be subsidized by the state. Like with wage protection, the government needs to allocate subsidies for workers whose wages are below the minimum wage.

\subsection{Healthcare Protection for Gig Workers: A Brief Case in Kediri}

Through the laws and regulations above, it can be concluded that in fact Indonesia already has regulations that guarantee protection or health insurance for gig workers. The question is the employers willing to implement the regulation, or in other words whether the regulation is effective in protecting health insurance for gig workers or not.

Gig economy also popular in Kediri. As in other cities in Indonesia, in Kediri, self-insurance protection is still less attractive to workers. There are private insurance companies that offer many security services to protect themselves. However, as we all know that insurance from private insurance companies requires a lot of money. And many workers in Indonesia can't afford it.

However, the Indonesian government always strives to guarantee worker rights including health protection. Article 27 paragraph (2) of the 1945 Constitution states that every citizen has the right to work that is decent for humanity. The 1945 Constitution of the Republic of Indonesia Article 28 D paragraph (2) states that everyone has the right to work and to receive fair and proper compensation and treatment in an employment relationship. This constitutional provision shows that workers as citizens have the right to receive protection in carrying out work in order to achieve their welfare.

In general, the Indonesian government already has a national health insurance program in the form of a Healthy Indonesia Card (KIS-Kartu Indonesia Sehat) which is integrated with the BPJS. However, employers who employ gig workers generally do not offer health care coverage, so gig workers are also less likely to have quality and affordable medical planning than other workers.

Based on the results of research conducted in the period July - September 2020 in Kediri, it shows that the awareness of Gig workers to have insurance is still low. About $55 \%$ of the respondents stated that health insurance is not their priority. Only $45 \%$ respondent have health insurance. For Gig workers who have health insurance, the most types of Health insurance that they owned are BPJS for Self Employed (34\%), followed by BPJS for Non-Wages Recipient (30\%), BPJS Ketenagakerjaan $(24 \%)$ and Jamkesmas (12\%). This shows that employers' 
awareness of including their gig workers is still low. This is evidenced by the results of research which show that most gig workers have health insurance on their own initiative, not the employee initiative.

\section{CONCLUSION}

COVID-19 is the cause of this slowdown in human activity, the disease that was first reported in Wuhan, China on December 31, 2019, became a global health issue and was later declared a pandemic by the Worlds Health Organization (WHO). Starting from one country, this disease became a global health issue and was later declared a pandemic. To prevent further spread of disease, many countries in the world implement social and physical distancing policies or in Indonesia this policy is called Pembatasan Sosial Berskala Besar (PSBB).

Indonesia already has a national health insurance program in the form of a Kartu Indonesia Sehat (KIS-Indonesian Healthy Card). People who work on the gig economy are particularly vulnerable to coronavirus and other harmful pathogens because they still need travel to multiple places and have close contact with customer. Gig workers often do not have paid sick leave, and also less likely than other workers to be able to simply take time off when sick. These jobs typically pay on low wages, gig workers tend to be particularly financially precarious, and seeing a doctor can be a challenge as well. Gig companies do not generally offer health insurance, so gig workers are also less than other workers to have a quality, affordable medical plan.

Based on the results of research conducted in the period July - September 2020 in Kediri, it shows that To have health insurance is not the priority. For gig workers who have health insurance, the most types the most types of Health insurance that are owned are BPJS for Self Employed. This shows that employers' awareness of including their gig workers is still low and most gig workers have health insurance on their own initiative, not the employee initiative.

\section{REFERENCES}

[1] World Health Organization, "WHO Timeline - COVID-19," Who, 2020.

[2] E. Ekaraahendy, F. F. Izzati, Farhanah, I. Raharjo, and R. Apinino, "Mengubur Pundi di Tengah Pandemi," 2020.

[3] N. Koutsimpogiorgos, J. Van Slageren, and A. M. Herrmann, "Conceptualizing the Gig
Economy and Its Regulatory Problems," Policy \& Internet, pp. 1-21, 2020, doi: 10.1002/poi3.237.

[4] R. B. Collier, V. B. Dubal, and C. Carter, "Labor Platforms and Gig Work: The Failure to Regulate," no. 106, 2017.

[5] A. Stewart and J. Stanford, "Regulating work in the gig economy: What are the options?," 2017, doi: $10.1177 / 1035304617722461$.

[6] W. Bruurmijn, M. Adelaida, D. Ortega, F. Bregiannis, and E. Calon, "Identification of Practical Problems and Possible Solutions," no. July, 2017, doi: 10.13140/RG.2.2.21444.32646.

[7] I. Note, "Protection of labour rights of " gig workers " in selected places," 2019.

[8] M. RI, Kepmen-No-KEP.100-MEN-VI2004. 2004. 